\title{
Phenotypic selection in an intertidal snail: effects of a catastrophic storm
}

\author{
Geoffrey C. Trussell* \\ Department of Zoology/Center for Marine Biology, University of New Hampshire, Durham, New Hampshire 03824, USA
}

\begin{abstract}
Littorina obtusata exhibits clear morphological variation (e.g. shell height, shell length, and aperture area) among shores differentially exposed to wave energies. Selection imposed by the hydrodynamic environment is often invoked to explain the correlation between morphology and wave exposure in intertidal organisms, but rarely is this hypothesis tested. I examined the effects of a catastrophic storm on the shell length and relative shell height and aperture area of $L$. obtusata populations on 2 protected and 1 wave-exposed shore in New England (USA) to test this hypothesis. Snails sampled after the storm had relatively squatter shells than those sampled before the storm, which is consistent with the pattern in shell height found in natural populations. The rapid shift supports the hypothesis that shell morphology on wave-exposed shores reflects, in part, selection imposed by hydrodynamic stress. Compared to morphological differences found between natural populations, shifts in relative shell height after the storm were small. Hence, despite its magnitude, the impact of this storm may be limited by available variation in relative shell height, especially if selection pressures operating during 'typical' conditions have depleted variation in this trait. There were 2 surprising results. First, relative aperture area decreased after the storm. This result is counter-intuitive because one would expect a shift to larger apertures, which can accomodate a larger adhesive foot. Second, a decrease in shell length after the storm was found only at the wave-exposed site, suggesting that the effects of the storm were more pronounced on this population. Because a shift in relative shell height and aperture area occurred at all 3 sites, these traits appear to be more sensitive to large storms than is shell length. The shifts in both relative shell height and aperture area may reflect differences in the hydrodynamic properties of shells collected before and after the storm, but I suggest that the shifts were mediated by the ability of snails to avoid free-stream flows by hiding in sheltered crevices. Both reduced shell height and aperture area may be advantageous when trying to fit into sheltered microhabitats during periods of increased hydrodynamic stress. In particular, the shift in aperture area may reflect the premium on successful crevice use over conventional adhesion during periods of extreme wave energies. Finally, while recent work on intertidal snails has emphasized the importance of phenotypic plasticity to morphological differentiation among populations, my results suggest that selection can assume a more prominent role during unusual events like this storm.
\end{abstract}

KEY WORDS: Catastrophic storm - Hydrodynamic forces - Littorina obtusata - Morphological variation. Phenotypic and natural selection. Wave energies

\section{INTRODUCTION}

Wave energy on intertidal shores varies considerably in both space and time and is thought to exert a strong influence on morphological variation in intertidal spe-

\footnotetext{
- Present address: School of Marine Science/VIMS, College of William and Mary, Gloucester Point, Virginia 23062, USA. E-mail: gct@vims.edu. Correspondence: 222 Upland Road, Cambridge, Massachusetts 02140, USA
}

cies (Kitching et al. 1966, Palumbi 1984, 1986, Denny et al. 1985, Etter 1988a, Trussell et al. 1993). One consequence of increased wave energy is the increased risk of dislodgement for organisms living in the intertidal zone. The risk of dislodgement may interfere with various aspects of a wave-swept existence (Menge 1974, Menge 1978a, b, Denny et al. 1985, Brown \& Quinn 1988, Etter 1989), and may be lethal if individuals are removed from their typical environment (Etter 1988a) or if wave forces exceed the individual's structural 
strength (Denny 1988). The magnitude of hydrodynamic forces (drag, lift, and acceleration reaction) is expected to be greatest on wave-exposed shores because mean and maximum water velocities and accelerations are greater (Denny 1985, 1988, Denny et al. 1985, Denny \& Gaines 1990). On wave-exposed shores natural selection is expected to favor traits that reduce the risk of dislodgement.

The risk of dislodgement for intertidal snails is dependent on a number of factors, including flow velocity and acceleration, shell shape and size, and the adhesive strength of the foot (Etter 1988a, Trussell et al. 1993, Trussell 1997). For snails to resist dislodgement, their adhesive ability, which is a function of foot size (Trussell et al. 1993, Trussell 1997), must exceed the magnitude of the hydrodynamic forces acting on the snail. Wave-imparted hydrodynamic forces act directly on the snail's shell so shell shape and size can reduce the risk of dislodgement in 2 ways. Changes in shell shape and size may (1) directly alter the magnitude of hydrodynamic forces acting on the shell, and (2) influence a snail's ability to hide from free-stream flows in sheltered cracks or crevices.

Morphological variation in intertidal snails is often correlated with differences in wave energies (Kitching et al. 1966, Kitching 1976, Kitching \& Lockwood 1974 , Raffaelli 1978, Crothers 1983, Johannesson 1986, Etter 1988a, Trussell et al 1993. Trussell 1996, 1997). In general, predation by crab predators on protected shores and dislodgement by wave forces on wave-exposed shores are believed to be the major forces driving habitat-specific differences in shell morphology (Kitching et al. 1966, Reimchen 1982, Palmer 1985, Trussell 1997). Typically, the shells of snails on wave-exposed shores are thinner, squatter relative to shell length, smaller-sized, and larger-apertured than those of protected conspecifics. In addition, wave-exposed snails typically have a larger adhesive foot than similarlysized protected conspecifics and are therefore able to resist greater dislodgement forces. Hence, the above traits are expected to reduce the risk of dislodgement for snails on wave-exposed shores.

It is clear that wave energies, particularly on waveexposed shores or during large storms, are an important agent of disturbance in intertidal communities (Suchanek 1978, 1981, Sousa 1979, 1984, Paine \& Levin 1981). Disturbances are discrete events that can displace or kill individuals or populations, and are often defined by their intensity of impact and frequency of occurrence (Sousa 1984). Here, I examine the impact of a catastrophic storm on the shell morphology of the intertidal snail Littorina obtusata. This storm was classified as a '50-year storm' and is one of the largest on record for the Gulf of Maine (Davis \& Dolan 1992) The storm lasted for $144 \mathrm{~h}$ and had wave heights reaching $\sim 11 \mathrm{~m}$ (Davis \& Dolan 1992); wave heights of $10 \mathrm{~m}$ were observed at the Canoe Beach Cove study site (G. Trussell \& J. Witman pers. obs.).

I evaluated the effects of the storm on Littorina obtusata shell morphology by collecting pre- and poststorm samples from a wave-exposed and 2 protected shores. In considering shell shape. I focused on shell height relative to shell length because previous work (Trussell et al. 1993, Trussell 1997) on several populations found obvious differences in relative shell height that were associated with wave-exposure. I also made measurements of aperture length and width to calculate aperture area, which can serve as a predictor of snail adhesive ability (Palmer 1992). Finally, I evaluated the storm's effect on snail size by using shell length as my size criterion.

\section{MATERIALS AND METHODS}

I made pre-storm measurements of shell height, shell length, aperture length and width to characterize shell traits and tenacity of a wave-exposed [Pemaquid Point, Maine (43⒌ $\left.50^{\prime} \mathrm{N}, 69^{\circ} 39^{\prime} 12^{\prime \prime} \mathrm{W}\right)$ ] and 2 protected [South Harpswell, Maine $\left(43^{\circ} 43^{\prime} 54^{\prime \prime} \mathrm{N}\right.$, $70^{\circ} 02^{\prime} \mathrm{W}$ ); Canoe Beach Cove, Nahant, Massachusetts $\left.\left(42^{\circ} 25^{\prime} 42^{\prime \prime} \mathrm{N}, 70^{\circ} 55^{\prime} 48^{\prime \prime} \mathrm{W}\right)\right]$ populations of Littorina obtusata in New England. Detalled descriptions of these sites are provided elsewhere (Trussell et al. 1993. Trussell 1997). Shell height was measured as the maximum distance perpendicular to the plane of the aperture and the highest point of the shell and shell length as the maximum dimension of the shell parallel to the plane of the aperture (see Fig 1 in Trussell et al. 1993). Aperture width (AW) was measured as the maximum dimension of the aperture running perpendicular to the axis of shell length. Aperture length (AL) was measured as the maximum dimension of the aperture along the same axis as the shell length measurement. Aperture area was calculated from these measurements assuming an elliptical shape using the formula $0.25 \pi$ (AW $\times$ AL) (Miller 1974, Lowell 1986). Measurements were made with digital calipers to the nearest $0.01 \mathrm{~mm}$. Snails were sampled (Table 1) from $0.25 \mathrm{~m}^{2}$ quadrats blindly tossed on each shore at the same tidal height $[-15$ to 2 m mean low water (M.LW)].

Soon after this sampling a catastrophic storm occurred from October 28 to 31, 1991. In addition to direct observation of wave heights near $10 \mathrm{~m}$ at the Canoe Beach Cove site, I obtained wind speed data recorded during the storm and the latter half of 1991 (Fig. 1) Wind speeds, in addition to fetch and the duration that the wind blows, can be used to estimate wave heights and wave forces experienced by inter- 


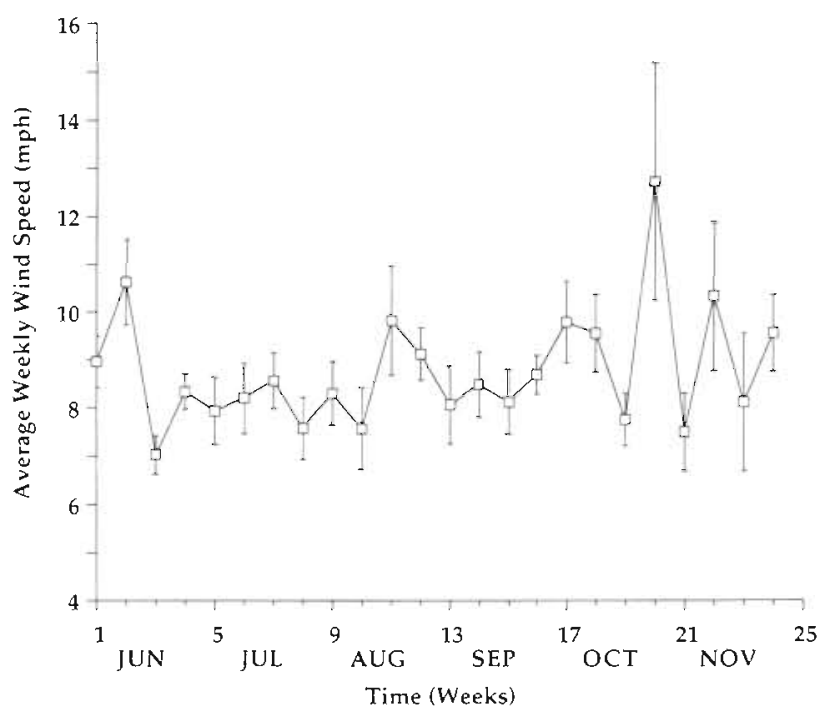

Fig. 1. Average weekly wind speeds $( \pm \mathrm{SE})$ for the latter half of 1991. Maximum wind speeds of $80 \mathrm{mph}\left(129 \mathrm{~km} \mathrm{~h}^{-1}\right)$ and wave heights of $-10 \mathrm{~m}$ were recorded at Nahant, Massachusetts (where the Canoe Beach Cove site is located). Data were recorded at the Portland, Maine International Jetport and obtained from the National Oceanic and Atmospheric Administration, Asheville, North Carolina

tidal organisms (Denny 1988). Due to the magnitude of this storm, storm surges elevated water velocities and accelerations far above their typical levels on each shore. Because wave-imparted forces are directly proportional to water velocity and acceleration (Denny et al. 1985), snails must have experienced greater hydrodynamic zorces during this storm than during conditions of normal wave energy. Hence, the probability of snail dislodgement was increased on each shore.

To test the effect of increased wave energies on shell morphology, I repeated measurements of shell height, shell length and apertu=e length and width using the methods described above on post-storm samples of snails from each population. Post-storm samples were collected 1 to $3 \mathrm{wk}$ after the storm from each population at the same tidal height and location as pre-storm samples (Table 1).

Statistical analyses. I conducted analyses of covariance (ANCOVA) to determine (1) pre-storm differences in relative shell height and aperture area between the 3 study sites, and (2) differences in relative shell height and aperture area between pre- and poststorm samples for each population. In all ANCOVAs I used shell length as the covariate to adjust for size effects on shell height and aperture area. For those ANCOVAs involving aperture area, both shell length and aperture area were $\log _{10}$ transformed. Otherwise, analyses were performed on untransformed data using Type III sums of squares (Wilkinson 1989). I also used ANOVA on shell length data to examine size differences between populations and before and after the storm.

\section{RESULTS}

\section{Pre-storm comparisons}

The ANCOVA on pre-storm samples from the 3 sites indicated homogeneity of slopes $\left(F_{12,139)}=1.95 ; \mathrm{p}>\right.$ 0.05 ) and that snails from both protected sites (Canoe Beach Cove and South Harpswell) had significantly taller shells in terms of relative shell height than waveexposed (Pemaquid Point) conspecifics $\left(F_{(2,141)}=\right.$ 150.27; $p<0.00001 ;$ Fig. 2, Table 2). ANOVA on shell length found that protected snails fom both sites were longer than those from the wave-exposed site $\left(F_{(2,142)}=\right.$ 18.21; $\mathrm{p}<0.00001$ )

Pre-storm comparison of aperture area relative to shell length revealed homogeneous slopes $\left(F_{(2,139)}=\right.$ 1.83; $p>0.05$ ) and that snails from both protected sites had smaller apertures than conspecifics from the wave-exposed site $\left(F_{(2.141)}=37.06 ; \mathrm{p}<0.00001\right.$; Fig 3, Table 2).

Table 1. Dates of sample collection for 3 populations of Littorina obtusata before and after the storm event. For populations having multiple sample dates for both before and after the storm (i.e. Canoe Beach Cove and South Harpswell) samples for each period were pooled

\begin{tabular}{|c|c|c|c|}
\hline Before storm & After storm & Time after storm (d) & Overall time difference (d) \\
\hline \multicolumn{4}{|c|}{ Pemaquid Point, Maine (wave-exposed) } \\
\hline Oct $24,1991(\mathrm{~N}=50)$ & Nov $22,1991(\mathrm{~N}=46)$ & 22 & 29 \\
\hline \multicolumn{4}{|c|}{ Canoe Beach Cove, Massachusetts (protected) } \\
\hline Sep 20, $1991(N=20)$ & Nov $8,1991(\mathrm{~N}=45)$ & 8 & 49 \\
\hline Oct $10,1991(\mathrm{~N}=25)$ & Nov $9,1991(\mathrm{~N}=45)$ & 9 & 30 \\
\hline \multicolumn{4}{|l|}{ South Harpswell, Maine (protected) } \\
\hline Oct $16,1991(\mathrm{~N}=25)$ & Nov $11,1991(\mathrm{~N}=83)$ & 18 & 33 \\
\hline Oct $24,1991(\mathrm{~N}=25)$ & & & 25 \\
\hline
\end{tabular}


Table 2. Littorina obtusata. Summary of least-squares regression statistics and range of shell lengths of snails in samples collected before (BS) and after (AS) the storm. Linear measurements are in mm and area measurements in $\mathrm{mm}^{2}$

\begin{tabular}{|c|c|c|c|c|}
\hline & Regression & $\mathrm{R}^{2}$ & $N$ & $\begin{array}{l}\text { Range of shell } \\
\text { lengths in sample }\end{array}$ \\
\hline \multicolumn{5}{|c|}{$\begin{array}{l}\text { Shell height ( } Y \text { ) vs shell length }(X) \text { : } \\
\text { Canoe Beach Cove }\end{array}$} \\
\hline BS & $Y=0.51 X+1.42$ & 0.94 & 45 & $7.77-14.64$ \\
\hline AS & $Y=0.51 X+1.31$ & 0.94 & 90 & $6.61-13.80$ \\
\hline \multicolumn{5}{|c|}{ South Harpswell } \\
\hline BS & $Y=0.55 X+1.07$ & 0.97 & 50 & $6.88-14.19$ \\
\hline AS & $Y=0.56 X+0.86$ & 0.98 & 88 & $4.72-14.23$ \\
\hline \multicolumn{5}{|c|}{ Pemaquid Pount } \\
\hline BS & $Y=0.52 X+0.70$ & 0.95 & 50 & $6.72-10.78$ \\
\hline AS & $Y=0.52 X+0.57$ & 0.93 & 46 & $6.40-10.66$ \\
\hline \multicolumn{5}{|c|}{$\begin{array}{l}\text { Aperture area }(Y) \text { vs shell length }(X) \text { : } \\
\text { Canoe Beach Cove }\end{array}$} \\
\hline BS & $Y=4.78 X-21.91$ & 0.95 & 45 & Same as above \\
\hline AS & $Y=4.52 X-19.94$ & 0.94 & 90 & Same as above \\
\hline \multicolumn{5}{|c|}{ South Harpswell } \\
\hline BS & $Y=4.75 X-21.12$ & 0.94 & 50 & Same as above \\
\hline$A S^{\circ}$ & $Y=4.89 X-24.28$ & 0.94 & 45 & $6.61-14.01$ \\
\hline \multicolumn{5}{|c|}{ Pemaquid Point } \\
\hline BS & $Y=5.03 X-21.12$ & 0.95 & 50 & Same as above \\
\hline AS & $Y=4.45 X-18.15$ & 0.95 & 46 & Same as above \\
\hline
\end{tabular}

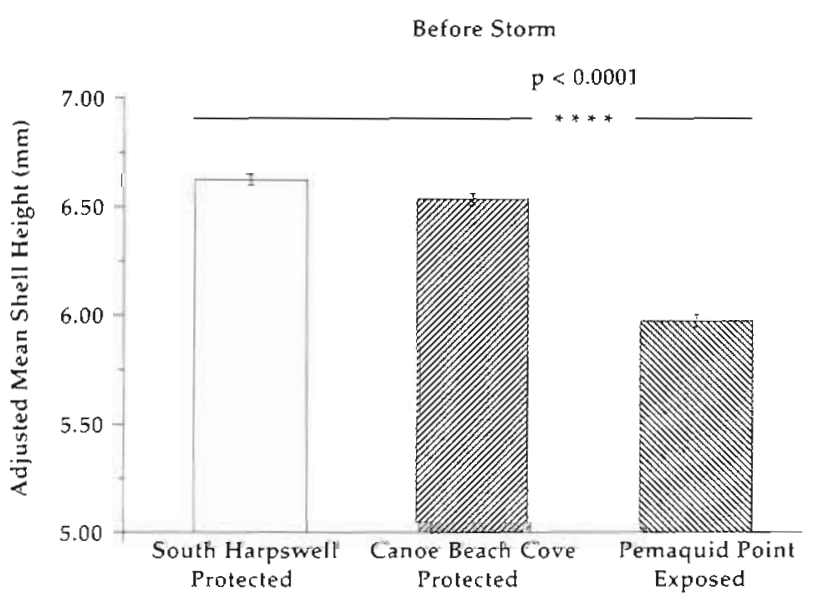

Fig. 2. Littorina obtusata. Adjusted mean shell height $\{ \pm \mathrm{SE}$ ] from ANCOVA for snals sampled before the storm from a wave-exposed and 2 protected shores in New England, USA. See Table 1 for sampling dates and Table 2 for regression statistics and sample sizes

\section{Pre-storm versus post-storm comparisons}

ANCOVAs on pre-and post-storm measurements of shell height as a function of shell length for each site found that slopes in all cases were homogeneous (all
Before Storm

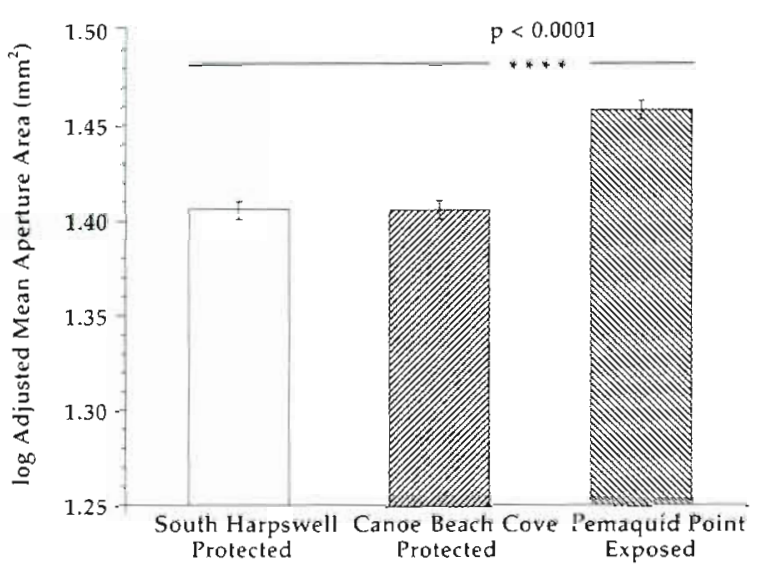

Fig. 3. Littorina obtusata. Adjusted mean log aperture area $( \pm \mathrm{SE})$ from ANCOVA for snails sampled before the storm from a wave-exposed and 2 protected shores in New England, USA. See Table 1 for sampling dates and Table 2 for regression statistics and sample sizes

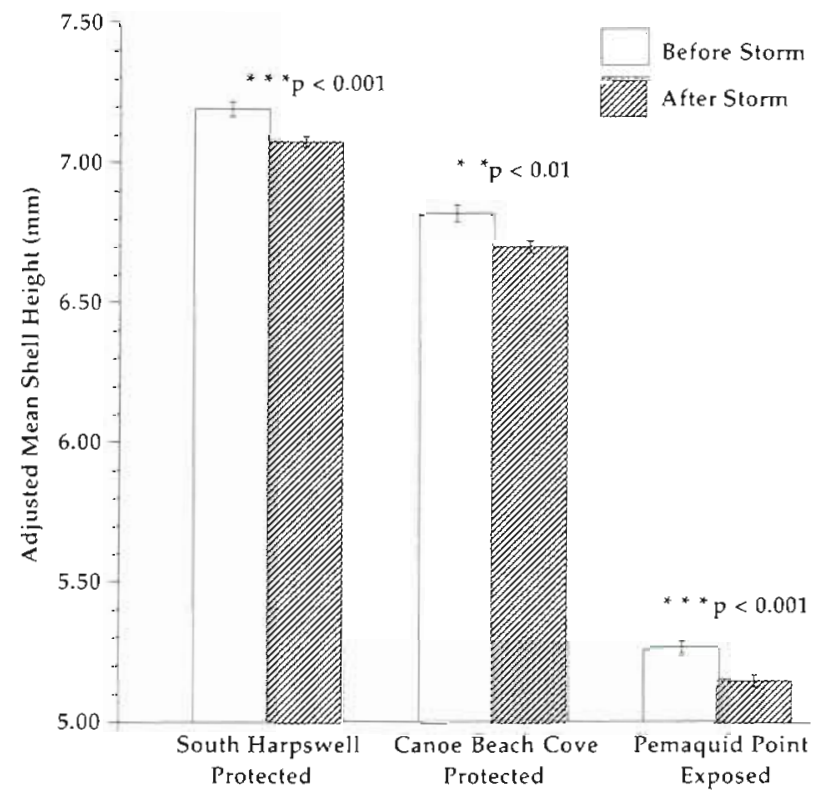

Fig. 4. Littorna obtusata. Adiusted mean shell height ( \pm SE) from ANCOVA for snals sampled before and after the storm at each study site. See Table 1 for sampling dates and Table 2 for regression statistics and sample sizes

$p \geq 0.551$. Snails measured before the storm from Canoe Beach Cove $\left(F_{|1,132|}=9.42 ; \mathrm{p}<0.005\right.$; Fig. 4), South Harpswell $\left(F_{11.135)}=12.33 ; \mathrm{p}<0.001\right.$; Fig. 4), and Pemaquid Point $\left(F_{(1.93)}=13.06 ; p<0.001 ;\right.$ Fig. 4$)$ all had taller shells relative to shell length than conspecifics measured from each site after the storm

ANCOVAs on aperture area as a function of shell length found that the apertures of post-storm samples were smaller than those of pre-storm samples collected. 


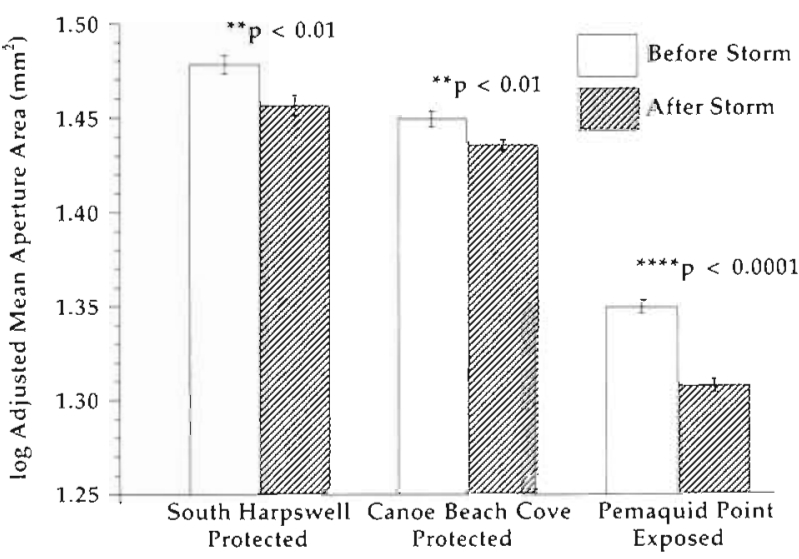

Fig. 5. Littorina obtusata. Adjusted mean log aperture area $( \pm S E$ ) from ANCOVA for snails sampled before and after the storm at each study site. See Table 1 for sampling dates and Table 2 for regression statistics and sample sizes

from Canoe Beach Cove $\left(F_{(1,132)}=8.85 ; \mathrm{p}<0.01\right.$; Fig. 5), South Harpswell $\left(F_{(1,92)}=8.47 ; \mathrm{p}<0.01\right.$; Fig. 5), and Pemaquid Point $\left(F_{1}, 0 .=71.66 ; p<0.00001 ;\right.$ Fig. 5). In all cases slopes were homogeneous (all $p$ at least $\geq 0.20)$.

ANOVA on shell length for samples collected before and after the storm detected a shift to smaller-sized shells at the wave-exposed site (Pemaquid Point: $\left.F_{(1,94)}=6.92 ; p<0.01\right)$. However, no differences in preversus post-storm shell length was detected at both protected sites (Canoe Beach Cove: $F_{11,133 \mid}=0.04: \mathrm{p}>$ 0.05 ; South Harpswell: $\left.F_{\{1,136\}}=3.01 ; \mathrm{p}>0.05\right)$.

\section{DISCUSSION}

Wave energy is believed to be an important selective force on many intertidal snail attributes. Although snail growth rates (Janson 1982, Brown \& Quinn 1988), reproductive output (Etter 1988b), and physiological stress (Etter 1989) are known to vary with gradients in wave-exposure, substantial emphasis has considered the influence of wave energy on snail shell form (Kitching et al. 1966, Kitching \& Lockwood 1974, Palmer 1985, Johannesson 1986, Trussell et al. 1993, Trussell 1996, 1997).

I found that the shells of protected snails were taller and smaller apertured relative to shell length than wave-exposed conspecifics (Figs. 2 \& 3). For relative shell height, the dramatic increase in water velocity and acceleration during the storm reinforced the pattern of relatively squatter shells as wave exposure increased. Snails measured from each population after the storm had significantly squatter shells relative to shell length than those measured before the storm
(Fig. 4). Hence, the natural experiment supports the hypothesis that among population variation in relative shell height is partly due to differences in wave energy among the 3 study sites. Compared to the morphological differences found between natural populations, shifts in relative shell height after the storm were small. Despite the magnitude of the storm recorded in this study, its impact on natural populations may have been limited by the available variation in relative shell height, especially if selection pressures operating during 'typical' conditions have depleted variation in this trait.

Selection against relatively taller shells by increased hydrodynamic forces may reflect 2 factors. First, a decrease in relative shell height may reduce the shell's coefficients of lift and/or drag; theoretically a reduction in either of these coefficients could reduce the magnitude of hydrodynamic forces acting on the snail's shell and thus the risk of dislodgement. For example, Dudley (1985) found that limpets from highly waveexposed environments had shells that experienced lower relative drag than those of limpets from sheltered environments (see also Branch \& Marsh 1978). Denny (1989) also reported a limpet shell shape that reduced drag but concluded that the conditions favoring streamlining, such as predictable flow direction and the absence of upstream objects (Vogel 1981), are unlikely to occur in the field. In addition, since both studies were conducted in laboratory flumes with orientation of shells into flow controlled, their relevance to field conditions is difficult to determine.

A second and perhaps more likely scenario is that relatively squatter shells will increase the availability of sheltered microhabitats for snails during periods of intense wave energy. Exclusion from sheltered cracks and crevices may force taller-shelled snails to bear the full brunt of storm surge. Crevice use in intertidal snails is common and the size structure of some snail populations is coupled with microhabitat size and availability. For example, Emson \& Faller-Fritsch (1976) increased the size structure of Littorina rudis populations by increasing crevice size, and Rafaelli \& Hughes (1978) found a tight relationship between the sizes of $L$. rudis and $L$. neritoides and the size of available crevices. Interestingly, the relationship documented by Rafaelli \& Hughes (1978) held for waveexposed shores but not protected shores suggesting that crevice size and availability are more important on wave-exposed shores in reducing the effects of waveimparted forces. L. obtusata on wave-exposed shores, especially after periods of increased wave action, are typically found in or near cracks and crevices, while protected-shore snails are typically found on the intertidal alga Ascophyllum nodosum (author's pers. obs.). If size-related exclusion from sheltered microhabitats 
is the mechanism accounting for my results, then crevice size and availability may be important on both wave-exposed and protected shores during unusually intense storms.

The crevice use hypothesis also explains the peculiar shift to smaller apertures after the storm in each population (Fig. 5). Intuitively, since aperture area is a reliable predictor of tenacity, one would expect a shift to larger apertures in response to increased hydrodynamic stress. This logic has been used to account for the typically larger apertures of wave-exposed snails, which are presumably capable of accomodating a larger adhesive foot. However, during unusually large storms the ability to exploit sheltered microhabitats is probably paramount in reducing the risk of dislodgement because it is unlikely that snails are able to withstand such intense free-stream flows via adhesion. The shift to both relatively squatter shells and smaller apertures probably reflects the premium on successful exploitation of sheltered crevices during larger storms. Despite this discussion, much remains to be learned about how and why the shift in aperture area occurred.

As expected, a shift to shorter shells after the storm occurred at the wave-exposed study site. Shorter shells could directly reduce the magnitude of hydrodynamic forces (Denny et al. 1985) and, like relatively squatter shells and smaller apertures, may improve the ability to hide in sheltered microhabitats. However, this shift did not occur at the protected sites. These results imply that the effects of the storm were only pronounced enough at the wave-exposed site to elicit a shift to shorter shells. If so, then it appears that relative shell height and aperture area are more sensitive to the effects of large storms than shell length because the shift in both traits occurred at all 3 study sites.

Although the correlation between the change in relative shell height and aperture area and the storm suggests that selection occurred, the lack of direct evidence of storm-induced mortality requires that my results be viewed with caution. However, if snails were able to survive being swept to the subtidal, I think the amount of time that samples were taken after the storm (Table 1) was probably sufficient for survivors to return to the intertidal zone.

While both pre-and post-storm samples were taken at the same tidal height and location on each shore, other factors such as storm or seasonally-induced migration downshore out of my sampling areas could also explain the morphological shifts I detected. For example, harsh weather conditions are known to restrict foraging behavior in Nucella lapillus (Burrows \& Hughes 1989). I think it unlikely, however, that snails would migrate large distances downshore during unusually intense storms. Instead, I would expect snails to seek the nearest available crevice and remain stationary until conditions improve, especially since Miller (1974) showed that the ability of snails to remain attached to the substratum (tenacity) is reduced when crawling. Hence, the risk of dislodgement for migrating snails during intense storms would be greater than that for snails remaining in crevices. Fletcher (1990) detected no seasonal effects on the vertical zonation of Littorina obtusata suggesting that pronounced seasonal migrations do not occur. Despite my arguments, these and other snail behaviors may be involved and more research is needed to determine their potential influence on the morphological changes I observed.

In summary, the precise mechanism responsible for the morphological shifts I observed remains unclear. However, I suggest that both relative shell height and aperture area, or factors related to them (Endler 1986), have an important role in reducing the wave-imparted hydrodynamic forces acting on snails during large storms. Moreover, the shift in relative shell height is consistent with differences observed among natural populations experiencing different wave energies. This result suggests that increased water velocities and accelerations may, directly or indirectly, serve as potent selective forces on shell morphology that contribute to variation in gastropod shell form on shores differentially exposed to wave action. Although phenotypic plasticity in snail traits such as foot size (Etter 1988a, Trussell 1997) and shell thickness (Appleton \& Palmer 1988, Palmer 1990, Trussell 1996) have demonstrated that selection is not the sole factor responsible for morphological differences among populations, my results suggest that selection can assume a more prominent role during unusual events like this storm (Bumpus 1899, Boag \& Grant 1981, Endler 1986).

Acknowledgements. This research was supported by grants from Sigma Xi, the Scientific Research Society, the Hawaiian Malacological Society, and the Lemer-Gray Fund of the American Museum of Natural History. Support during writing was provided by a School of Marine Science Fellowship (College of Willam \& Mary). [ thank S. Genovese, T Kocher, R. Olson, W. Sobczak, and G. Vermeij for helpful comments on earlier drafts. I also thank J. Ayers and J. Witman for providing me with laboratory space during my course of study at Northeastern University's Marine Science Center. Special thanks to R. Etter and R. Palmer for their insight and extensive contribution to this work.

\section{LITERATURE CITED}

Appleton RD, Palmer AR (1988) Water-borne stimuli released by crabs and damaged prey induce more predator-resistant shells in a marine gastropod. Proc Natl Acad Sci USA 85:4387-4391

Boag PT, Grant PR (1981) Intense natural selection in a population of Darwin's tinches (Geospizinae) in the Galapogos. Science 214:82-85

Branch GM, Marsh AC (1978) Tenacity and shell shape in six 
Patella species: adaptive features. J Exp Mar Biol Ecol 34 $111-130$

Brown KM, Quinn JF (1988) The effect of wave disturbance on growth in three species of intertidal gastropods. Oecologia $75: 420-425$

Bumpus $\mathrm{HC}$ (1899) The elimination of the unfit as illustrated by the introduced sparrow, Passer domesticus. Mass. Biological Lectures, Marine Biological Laboratory, Woods Hole. Ginn and Co., Boston. p 209-226

Burrows MT, Hughes RN (1989) Natural foraging of the dogwhelk, Nucella lapillus (Linnaeus); the weather and whether to feed. J Mollusc Stud 55:285-295

Crothers JH (1983) Some observations on shell shape variation in North American populations of Nucella lapillus (L.). Biol J Lin Soc 19:237-274

Davs RE, Dolan RJ (1992) The 'All Hallows' Eve' coastal storm-October, 1991. J Coastal Res 8.978-983

Denny MW (1985) Waves forces on intertidal organisms: a case study. Limnol Oceanogr 30:1171-1187

Denny MW (1988) Biology and the mechanics of the waveswept environment. Princeton Unjversity Press, Princeton

Denny MW (1989) A limpet shell shape that reduces drag: laboratory demonstration of a hydrodynamic mechanism and an exploration of its effectiveness in nature. Can J Zool 67:2098-2106

Denny MW, Daniel TL, Koehl MAR (1985) Mechanical lumits to size in wave-swept organisms. Ecol Monogr 55:69-102

Denny MW, Gaines SD (1990) On the prediction of maximal intertidal wave forces. Limnol Oceanogr 35:1-15

Dudley R (1985) Fluid-dynamic drag of limpet shells. Veliger 28:6-13

Emson RH, Faller-Fritsch RJ (1976) An experimental investigation into the effect of crevice avalability on abundance and size structure in a population of Littorina rudis (Maton): Gastropoda: Prosobranchia. J Exp Mar Biol Ecol 23:285-297

Endler JA (1986) Natural selection in the wild. Princeton University Press, Princeton

Etter RJ (1988a) Asymmetrical developmental plasticity in an intertidal snail. Evolution 42:322-334

Etter RJ (1988b) Physiological stress and color polymorphism in the intertidal snail Nucella Iapillus. Evolution 42 $660-680$

Etter RJ (1989) Life history variation in the intertidal snail Nucella lapillus across a wave-exposure gradient. Ecology $70: 1857-1876$

Fletcher CR (1992) Distribution of the flat periwinkles Littorina obtusata (L.) and L. mariae Sacchi \& Rastelli (Gastropoda: Prosobranchia): relationship to the slope of the shore. Proc Int Symp Littorinid Biol 3:119-126

Janson K (1982) Genetic and environmental effects on the growth ratc of Littorina saxatilis. Mar Biol 69:73-78

Johanesson B 1 1986) Shell morphology of Littonna saxatilis Olivi: the relative importance of physical factors and predatıon. J Exp Mar Biol Ecol 102:183-195

Kitching JA (1976) Distribution and changes in shell form of Thals spp. (Gastropoda) near Bamfield, B.C. J Exp Mar Biol Ecol 23:109-126

Kitchung JA, Lockwood J (1974) Observations on shell form and its ecological significance in thasid gastropods of the genus Lepsiella in New Zealand. Mar Biol 28:131-144

Kitching JA, Muntz L, Ebling FJ (1966) The ecology of Lough Ine. XV. The ecological significance of shell and body

This article was presented by K. L. Heck Jr (Senior Editorial Advisor), Dauphin Island, Alabana, USA forms in Nucella. J Anim Ecol 35:113-126

Lowell RB (1986) Crab predation on limpets: predator behavior and defensive features of the shell morphology of the prey. Biol Bull 171:577-596

Menge BA (1974) Effect of wave action and competition on brooding and reproductive effort in the seastar Leptasterias hexactis. Ecology 55:84-93

Menge BA (1978a) Predation intensity in a rocky intertidal community. Relation between predator foraging actuvity and environmental harshness. Oecologia 34:1-16

Menge BA (1978b) Predation intensity in a rocky intertidal community. Effect of an algal canopy, wave action and desiccation on predator feeding rates. Oecologia 34:17-35

Miller SL (1974) Adaptive design of locomotion and foot form in Prosobranch gastropods. J Exp Mar Biol Ecol 14:99-156

Paine RT, Levin SA (1981) Intertidal landscapes: disturbance and the dynamics of pattern. Ecol Monogr 51:145-178

Palmer AR (1985) Adaptive value of shell variation in Thais lamellosa: effect of thick shells on vulnerability to and their preference by crabs. Veliger 27:349-356

Palmer AR (1992) Intraspecific variation in three species of rocky shore gastropods from Hong Kong: correlations among habitats and a companson with temperate species. In: Morton B (ed) The marine flora and fauna of Hong Kong and southern China III. Hong Kong University Press, Hong Kong, p 649-691

Palumbi SR (1984) Tactics of acclimation: morphological changes of sponges in an unpredictable environment. Science 225:1478-1480

Palumbi SR (1986) How body plans limit acclimation: responses of a demosponge to wave force. Ecology 67 : 208-214

Raffaelli DG (1978) The relationship between shell injuries, shell thickness and habitat characteristics of the intertidal snajl Littorina rudis Maton. J Mollusc Stud 44:166-170

Raffaelli DG, Hughes RN (1978) The effect of crevice size and availability on populations of Littorina rudis and Littorina neritoides. J Anim Ecol 74:71-83

Reimchen TR (1982) Shell size divergence in Littorina mariae and $L$. obtusata and predation. Can J Zool 60:687-695

Sousa WP (1979) Experimental investigations of disturbance and ecological succession in a rocky intertidal algal community. Ecol Monogr 49:227-254

Sousa WP (1984) The role of disturbance in natural communities. Annu Rev Ecol Syst 15:353-391

Suchanek TH (1978) The ecology of Mytilus edulis L. in exposed rocky intertidal communities. J Exp Mar Biol Ecol $31: 105-120$

Suchanek TH (1981) The role of disturbance in the evolution of life history strategies in the intertidal mussels Mytilus edulis and Mytilus californianus. Oecologia 50:143-152

Trussell GC (1996) Phenotypic plasticity in an intertidal snail: the role of a common crab predator. Evolution 50:448-454

Trussell GC (1997) Phenotypic plasticity in the foot size of an intertidal snail. Ecology 78:1033-1048

Trussell GC, Johnson AS, Rudolph SG, Gilfillan ES (1993) Resistance to dislodgment: habitat and size-specific differences in morphology and tenacity in an intertidal snail. Mar Ecol Prog Ser 100:135-144

Wilkinson G(1989) SYSTAT the system for statistics. SYSTAT Inc, Evanston, IL

Vogel $S$ (1981) Lite in moving fluids. Princeton University Press, Princeton

Manuscript first received: March 26, 1996

Revised version accepted: March 13, 1997 